\title{
Spectroscopic study of binding of cationic Pheophorbide-a to antiparallel quadruplex Tel22
}

\author{
O. A. Ryazanova ${ }^{1}$, V. N. Zozulya ${ }^{1}$, I. M. Voloshin ${ }^{1}$, A. Yu. Glamazda ${ }^{1}$, \\ I. Ya. Dubey ${ }^{2}$, L. V. Dubey ${ }^{2}$, V. A. Karachevtsev ${ }^{1}$ \\ ${ }^{1}$ B. I. Verkin Institute for Low Temperature Physics and Engineering, NAS of Ukraine \\ 47, Prospekt Nauky, Kharkiv, Ukraine, 61103 \\ ${ }^{2}$ Institute of Molecular Biology and Genetics, NAS of Ukraine \\ 150, Akademika Zabolotnoho Str., Kyiv, Ukraine, 03143 \\ ryazanova@ilt.kharkov.ua
}

\begin{abstract}
Aim. To study the binding of a water-soluble cationic Pheophorbide-a derivative (CatPheo- $a$ ) ta a $\mathrm{Na}^{+}$-stabilized antiparallel quadruplex formed by 22-mer oligonucleotide d[ $\left.\mathrm{AG} 3\left(\mathrm{~T}_{2} \mathrm{AG}_{3}\right)_{3}\right]$ of the human DNA telomeric sequence (Tel22, PDB ID: 143D). Methods. Absorption and polarized fluorescence spectroscopy were used to determine the properties of DNA-ligand complexes. Fluorescence titration was applied to evaluate the Tel22 dye binding affinity. Absorption melting was used to estimate the effect of CatPheo- $a$ on thermodynamic parameters of the Tel22 quadruplex folding. IR spectroscopy was used to detect singlet oxygen generation . Results. CatPheo- $a$ was found to bind effectively to the Tel22 quadruplex via two competitive binding modes, which are characterized by opposite changes in the dye fluorescence. The spectroscopic properties of CatPheo- $a+$ Tel2 2 complexes were determined. Thermodynamic parameters of the Tel22 quadruplex folding with/without CatPheo- $a$ were calculated. Conclusions. CatPheo- $a$ destabilizes the quadruplex structure of Tel 22 with a twofold decrease in the equilibrium quadruplex folding constant at $37^{\circ} \mathrm{C}$. The efficiency of singlet oxygen generation by CatPheo- $a$ is higher than that by the anionic Pheo- $a$.
\end{abstract}

Ke y w o r d s: Pheophorbide- $a$, Tel22 quadruplex, polarized fluorescence, absorption, melting, thermodynamic parameters

\section{Introduction}

Porphyrins represent a large class of macrocyclic compounds with unique photophysical properties and great potential for application in biology, medicine and nanotechnology. One of them, Pheophorbide- $a$ (Pheo- $a$ ), is a wellknown chlorophyll metabolite characterized by the chlorine-type visible absorption spectrum $[1,2]$ with a high extinction coefficient in the red region where the transparency of tissues to light increases considerably. This dye

(C) 2019 O. A. Ryazanova et al.; Published by the Institute of Molecular Biology and Genetics, NAS of Ukraine on behalf of Biopolymers and Cell. This is an Open Access article distributed under the terms of the Creative Commons Attribution License (http://creativecommons.org/licenses/by/4.0/), which permits unrestricted reuse, distribution, and reproduction in any medium, provided the original work is properly cited 
selectively accumulates in the tumor cells that determines its widespread using as a photosensitizer for photodynamic therapy (PDT) of tumors [3-6]. One of the mechanisms of the Pheo- $a$ action on tumor tissues is based on the ability of the dye to produce singlet oxygen in cells under red light irradiation [7]. However, natural Pheo- $a$ has poor water solubility. It contains a carboxylic group, the anionic character of which complicates binding of the dye to negatively charged nucleic acids. To correct this disadvantage a novel cationic derivative of this dye containing a trimethylammonium group (CatPheo- $a$, Figure 1) was synthesized by us [8]. We supposed that transformation of Pheo- $a$ into a cationic compound would improve its DNA binding ability.

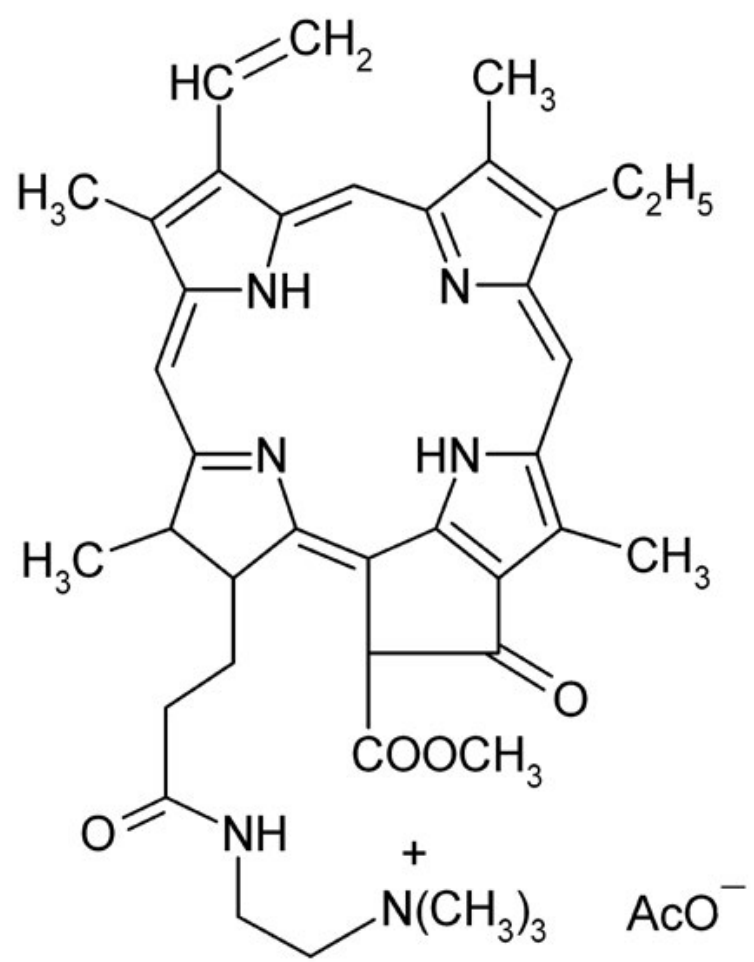

Fig. 1. Molecular structure of CatPheo- $a$.
The spectroscopic properties of CatPheo- $a$, as well as the ways of its binding to model synthetic biopolymers of different secondary structures (single stranded inorganic polyphosphate, double-stranded poly (A) poly(U), $\operatorname{poly}(\mathrm{G}) \cdot \operatorname{poly}(\mathrm{C})$ polynucleotides and fourstranded poly $(\mathrm{G})$ polynucleotides) were studied earlier under near-physiological ionic conditions using various spectroscopic techniques $[8,9]$. It was shown that CatPheo- $a$ binds to all these polymers, but especially effective binding was observed in the case of quadruplex poly $(G)$, evidently due to the structural features of the dye core which is appropriate for interaction with the G-tetrads through $\pi-\pi$ stacking interactions. Two types of CatPheo- $a$ complex with long four-stranded poly $(\mathrm{G})$ were revealed depending on the relative phosphateto-dye concentration ratio, $P / D$ [9]. The first one predominating at high dye content (low $P / D$ ) and characterized by weakening of the dye emission was identified as external binding of the dye to phosphate backbone with selfstacking. The second binding mode prevalent at high $P / D$ (presumably, intercalative binding) was accompanied by the enhancement of CatPheo- $a$ fluorescence. High affinity revealed for CatPheo- $a$ binding to guanine-rich nucleic acids gives the ground to assume the improved antitumor properties of the dye.

G-quadruplexes (G4) are specific fourstranded nucleic acid structures containing $\pi-\pi$ stacked guanine tetrads, normally stabilized by metal cations located between the tetrads to coordinate the guanine bases. They are considered as key regulatory elements in the genome regions of biological significance, in particular, in human telomeres and promoter regions of some proto-oncogenes [10-13]. 
They are known as promising targets for anticancer therapy, since G-quadruplex binding ligands, including many porphyrin derivatives, are able to inhibit the telomerase, a tumorassociated enzyme responsible for the telomere elongation [14-16]. We have recently found that CatPheo-a inhibits the telomerase in vitro at low micromolar concentrations being much more active than its precursor, anionic Pheo- $a$. $\mathrm{IC}_{50}$ values of these compounds in the modified TRAP assay [17] are $7.4 \mu \mathrm{M}$ and $>40 \mu \mathrm{M}$, respectively (from unpublished results). Therefore it seems appropriate to investigate the features of CatPheo- $a$ interaction with the nucleotide sequence corresponding to the human telomeric DNA, as well as to check its ability to generate singlet oxygen.

The subject of this study is CatPheo- $a$ binding to the $\mathrm{Na}^{+}$-stabilized 22-mer sequence of human telomeric DNA 5'-d $\left[\mathrm{AG}_{3}\left(\mathrm{~T}_{2} \mathrm{AG}_{3}\right)_{3}\right]-3^{\prime}$ (Tel22) containing three telomeric repeats TTAGGG. It is known that in the presence of monovalent cations $\left(\mathrm{K}^{+}, \mathrm{Na}^{+}\right)$single-stranded Tel22 can fold into quadruplex structures of different conformations and topologies. In $\mathrm{Na}^{+}-$ containing solutions it forms the intramolecular G-quadruplex with antiparallel basket-type conformation (PDB code 143D) where three G-tetrads are connected with one diagonal and two lateral (TTA) loops [18]. In our work the spectroscopic properties of the complexes formed between CatPheo- $a$ and Tel22 were studied in neutral aqueous buffered solutions, pH6.9, of near-physiological ionic strength at various polymer/ligand concentration ratios, $P / D$, ranged from 0 to 7 . An effect of the dye on the thermodynamic parameters of Tel22 folding was established, and the efficiency of singlet oxygen generation by CatPheo- $a$ was tested.

\section{Materials and Methods}

Materials. The CatPheo- $a$ was synthesized from Pheophorbide- $a$ (Frontier Scientific Inc., Logan, Utah) according to the procedure previously described in [8]. 22-mer oligonucleotide 5'- $\mathrm{d}\left[\mathrm{AG}_{3}\left(\mathrm{~T}_{2} \mathrm{AG}_{3}\right)_{3}\right]-3^{\prime}$ of human telomeric DNA from Eurogentec SA (Belgium) was used without further purification.

The $2 \mathrm{mM}$ phosphate buffer (pH6.9) containing $0.5 \mathrm{mM}$ EDTA and $0.1 \mathrm{M} \mathrm{NaCl}$ prepared from deionized water was used as a solvent.

Quadruplex structure of Tel22 was formed by heating the solution of oligonucleotide in a buffer containing $0.1 \mathrm{M} \mathrm{NaCl}$ at $95^{\circ} \mathrm{C}$ for 5 min followed by slow cooling to room temperature in accordance with the procedure [19].

Tel22 concentration was determined spectrophotometrically using the extinction value of $\varepsilon_{260}=228500 \mathrm{M}^{-1} \mathrm{~cm}^{-1}$ (in strands) at room temperature. The concentration of the dye was determined gravimetrically using the CatPheo- $a$ molecular weight value of 736.9 Da. It was $10 \mu \mathrm{M}$ in all samples.

Apparatus and techniques. The spectroscopic properties of CatPheo- $a$ and its complexes with Tel22 have been studied using polarized fluorescence and absorption spectroscopy. The effect of CatPheo- $a$ on thermodynamic parameters of the Tel22 quadruplex folding was determined using absorption melting techniques. The singlet oxygen generation by this dye was studied using near-infrared (NIR) spectroscopy. The sample solutions were filled in the quartz cells.

Electronic absorption spectra were recorded on SPECORD UV/VIS spectrophotometer (Carl Zeiss, Jena). 
Fluorescent measurements were carried out using a laboratory spectrofluorimeter based on the DFS-12 monochromator (LOMO, Russia, $350-800 \mathrm{~nm}$ range, dispersion $5 \AA / \mathrm{mm}$ ) by the method of photon counting as it was described earlier $[20,21]$. The fluorescence was excited by polarized beam of He-Ne laser $\left(\lambda_{\text {exc }}=633 \mathrm{~nm}\right)$ whose radiation was reduced by neutral density filters. The emission was observed at the $90^{\circ}$ angle from the excitation beam. Fluorescence spectra were corrected on the spectral sensitivity of the spectrofluorimeter. Ahrens prisms were used to analyze the fluorescence polarization. The spectrofluorimeter was equipped with a quartz depolarizing optical wedge to exclude the monochromator polarization-dependent response. The fluorescence intensity, $I$, and polarization degree, $p$, have been calculated using the formulas [22]:

$$
\begin{aligned}
& I=I_{I I}+2 I_{\perp} \\
& p=\left(I_{I I}-I_{\perp}\right) /\left(I_{I I}+I_{\perp}\right)
\end{aligned}
$$

where $I_{I I}$ and $I_{\perp}$ are intensities of the emitted light, which are polarized parallel and perpendicular to the polarization direction of exciting light, respectively.

Generation of the singlet oxygen by CatPheo- $a$ and its parent compound, Pheo- $a$, has been studied in ethanol solution under the same experimental conditions using the laboratory setup for measurements in NIR region based on IRS-31 monochromator (LOMO, Russia) equipped with InGaAs photodiode detector. The laser diode with $\lambda_{\text {exc }}=665 \mathrm{~nm} \mathrm{(12}$ $\mathrm{mW}$ ) was used for the luminescence excitation.

Binding of the CatPheo- $a$ to Tel22 was studied in titration experiment where dependences of the dye fluorescence intensity and polarization degree on the molar phosphateto-dye ratio, $P / D$, were measured at the constant dye concentration $(10 \mu \mathrm{M})$. For this we add the dye sample with increasing amounts of the concentrated stock solution of Tel22 quadruplex containing the same content of dye. Wavelength of observation was $\lambda_{\text {obs }}=677 \mathrm{~nm}$. $P / D$ values were in the range from 0 to 7 .

Absorption melting experiments were carried out at $295 \mathrm{~nm}$ in accordance with the procedure [23]. The quartz cell was allocated in the copper cell, the temperature in which was changed by the computer operated Peltier element. The cell was inserted into the spectrophotometer. The accuracy of the temperature measurement was $0.1{ }^{\circ} \mathrm{C}$.

All experiments were carried out at room temperature $\left(20-22{ }^{\circ} \mathrm{C}\right)$.

\section{Results and Discussion}

Absorption and fluorescent properties of CatPheo-a in a free state and bound to Tel22 quadruplex. Visible absorption spectra of CatPheo- $a$ in a free state and bound to $\mathrm{Na}^{+}-$ containing Tel 22 oligonucleotide measured in aqueous solution under the near-physiological ionic conditions are presented in Figure 2. The absorption spectrum of the free dye consists of the intense Soret band (B-band) located at $380 \mathrm{~nm}\left(\varepsilon_{380}=34200 \mathrm{M}^{-1} \mathrm{~cm}^{-1}\right)$ and four Q-bands [8] among which the most intensive peak is the longwave one with maximum at $682 \mathrm{~nm}\left(\varepsilon_{682}=16200 \mathrm{M}^{-1} \mathrm{~cm}^{-1}\right)$, that is typical for all chlorine derivatives $[1,2]$. These bands correspond to $\pi \rightarrow \pi^{*}$ transitions polarized within the plane of conjugated macrocycle. The porphyrin Soret band results from superposition of two mutually perpendicularly polarized intense electron transitions [24]. 
The fluorescence spectrum of free CatPheo- $a$ represents a broad band with a maximum at $668 \mathrm{~nm}$ and a longwave shoulder [8]. It can be fitted by the sum of two Gaussian components centered at 668.5 and $702.5 \mathrm{~nm}$. Both emission bands have been found to belong to vibrational structure of a single electronic transition: the first band corresponds to a linear oscillator, whereas the second band corresponds to a planar oscillator $[25,26]$. The fluorescence polarization degree measured in the band maximum is $p=0.015$. The unusual relative location of the CatPheo- $a$ longwave absorption band maximum (682 nm) and emission one $(668 \mathrm{~nm})$ are characteristic for some pheophorbide derivatives in aqueous solution. The same mutual disposition of these bands maxima was observed earlier for the parent dye, Pheo- $a$ [27], and pyropheophorbide [28].

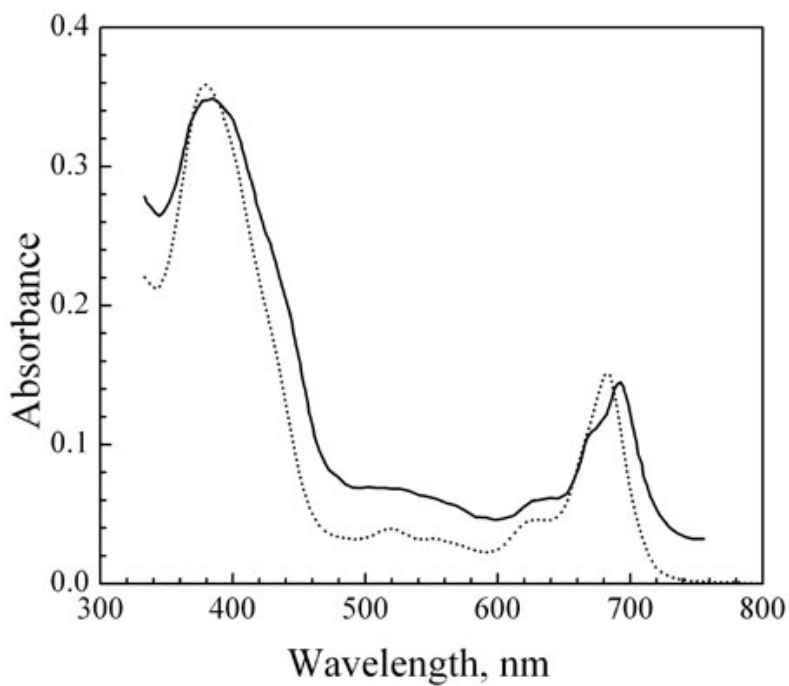

Fig. 2. Absorption spectra of CatPheo- $a$ in a free state (dotted line-) and bound to Tel22 quadruplex at $P / D=4.5$ (solid line) measured in $2 \mathrm{mM}$ phosphate buffer containing $0.5 \mathrm{mM}$ EDTA and $0.1 \mathrm{M} \mathrm{NaCl}, \mathrm{C}_{\text {dye }}=10 \mu \mathrm{M}$, light path $1 \mathrm{~cm}$.
So, for Pheo- $a$ in a phosphate buffer containing $1 \%$ ethanol the emission and the absorption band maxima were located at 660 and $685 \mathrm{~nm}$, respectively [29]. It has been also revealed that the longwave maximum of the excitation spectrum of Pheo- $a$ is blue shifted to $656 \mathrm{~nm}$ in comparison with the corresponding absorption one $(685 \mathrm{~nm})$ [30]. As long as a band shape of the excitation spectrum was found to be independent of the emission wavelength, the conclusion was made that only one emitting species exists, namely dye monomers. Study on the dependence of the pheophorbide- $a$ spectra on the dye concentration [27], water/alcohol ratio [27] and temperature [29] allowed to conclude that in aqueous solution at working concentration of $10 \mu \mathrm{M}$ the dye is mainly in dimeric form. The absorption band of Pheo- $a$ dimers was shown to be located at $685 \mathrm{~nm}$, whereas the monomeric one (in aqueous solution it is shortwave hidden band) is at $667 \mathrm{~nm}$ [27]. The similar behavior is observed for CatPheo- $a$ in water, its longwave band in the absorption spectrum has asymmetric shape. It includes shortwave hidden band which can be assigned to the dye monomers. Thus, maximum of the longwave absorption band was attributed to dimeric form of the dye, whereas the emission band maximum was assigned to the dye monomers [9]. It was shown [9] that CatPheo- $a$ dimers are fairly stable, their disintegration starts at the temperature above $70{ }^{\circ} \mathrm{C}$, and it is accompanied by a substantial increase in intensity of the dye absorption and emission.

The binding of CatPheo- $a$ to Tel22 results in the transformation of the dye spectra. At $P / D=4.5$ the absorption spectrum of the bound dye exhibits hypochromism, red shift 
and broadening of the bands in comparison with those observed for unbound one (Figure 2). The Soret absorption band undergoes $4 \mathrm{~nm}$ red shift (to $384 \mathrm{~nm}$ ), whereas longwave Q-band splits into two components (it can be fitted by the sum of two Gaussian components centered at 667 and $692 \mathrm{~nm}$ ), so its maximum is $10 \mathrm{~nm}$ red shifted relative to that of the free dye. Appearance of the background on the edges of the spectrum is conditioned by an increase in the solution turbidity. This phenomenon can be caused by the formation of dye-oligomer aggregates at near-stoichiometric (by charge) condition that induces an appearance of the light scattering. So, the formation of extended porphyrin-biopolymer aggregates at similar condition was observed earlier for other porphyrin derivatives [21].

At the same time, binding to Tel22 results in substantial enhancement of the CatPheo- $a$ emission, rise of the fluorescence polarization degree up to 0.2 , as well as $14 \mathrm{~nm}$ red shift of the fluorescence band maximum (to $682 \mathrm{~nm}$ ) that can indicate withdrawal of the dye molecules from aqueous environment and the formation of complex with $\pi$-stacking between their chromophores and nucleic bases.

Analysis of the absorption and fluorescence spectra (band assignment) of the CatPheo- $a+$ Tel22 complex is complicated due to the fact that the sample may contain several components: a free dye, bound dye monomers (the charged moiety of the dye is electrostatically bound to the Tel22 phosphates, whereas the chromophore can be embedded into the groove or bind via end-stacking to external G-tetrad), bound dye dimers or trimers. For each component, the presence of at least 2 bands (vibrational structure) is observed. The longwave absorption band of the CatPheo-a + Tel22 complex is asymmetric with a short-wavelength shoulder (Fig. 2). So it represents a superposition of at least two bands. Decomposition of the spectrum into Gaussian components gives the bands with maxima at $667 \mathrm{~nm}$ (hidden band) and at $692 \mathrm{~nm}$ (more intense one). The emission band of the CatPheo- $a+$ Tel 22 complex (Fig. 3) also has asymmetric shape. Fitting the spectra to a sum of Gaussian components gives several components: shortwave band centered at $673-678 \mathrm{~nm}$, at $682 \mathrm{~nm}$ and approximately at $730 \mathrm{~nm}$. We assume that the band, which is manifested most intensively in the absorption spectrum (692 nm), corresponds to such a form of a bound dye that weakly fluoresces or to the hidden fluorescence band centered approximately at $730 \mathrm{~nm}$, whereas the hidden absorption band at $667 \mathrm{~nm}$ obviously corresponds to the species with fluorescence maximum of $682 \mathrm{~nm}$.

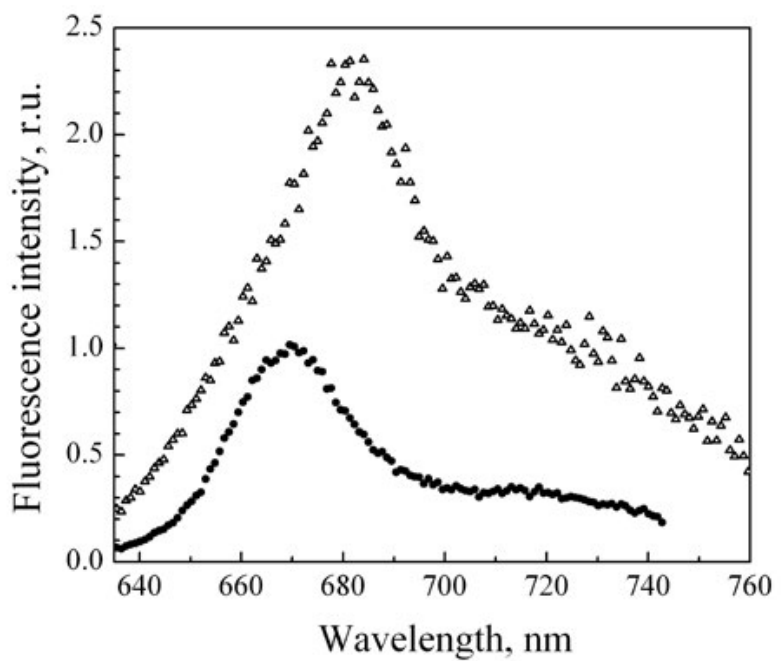

Fig. 3. Fluorescence spectra of CatPheo- $a$ in a free state $(\bullet)$ and bound to Tel22 quadruplex at $P / D=4.5(\Delta)$ in $2 \mathrm{mM}$ phosphate buffer containing $0.5 \mathrm{mM}$ EDTA with $0.1 \mathrm{M} \mathrm{NaCl}, \mathrm{C}_{\text {dye }}=10 \mu \mathrm{M}, \lambda_{\text {exc }}=633 \mathrm{~nm}$. 
It was shown that CatPheo- $a$ is able to produce singlet oxygen in ethanol solution under irradiation by red light with $\lambda_{\text {exc }}=665 \mathrm{~nm}$. The spectrum represents a single band in the near IR range with maximum at $1272 \mathrm{~nm}$ with full width at the half maximum amounted by approximately $20 \mathrm{~nm}$. The relative quantum yield of singlet oxygen produced by CatPheo- $a$ is approximately $15 \%$ higher than that for anionic Pheo- $a$ at the same experimental condition. However, no generation of singlet oxygen was detected in $\mathrm{D}_{2} \mathrm{O}$ solution (without detergent) for both CatPheo- $a$ and Pheo- $a$, probably, due to dimerization or aggregation of the dyes that is consistent with the data [7]. It is proved that Pheo- $a$ has photodynamical activity in vivo and produces singlet oxygen in the cells. Thus, it is expected that CatPheo- $a$ will be also effective photosensibilizer for PDT of tumor.

\section{Fluorescent titration study of the} CatPheo-a binding to Tel22 quadruplex. Binding affinity of CatPheo- $a$ to Tel22 antiparallel quadruplex was studied in the fluorescence titration experiments. Figure 4 shows the dependence of the dye fluorescence intensity and polarization degree measured at $\lambda_{\text {obs }}=$ $677 \mathrm{~nm}$ on relative concentration of Tel22 in solution within $P / D$ range from 0 to 7 . As seen in the figure the titration curve is biphasic that points out the existence of two different binding modes. In first (at $P / D<0.7$ ), the formation of complex between the cationic dye and the anionic oligonucleotide is accompanied by slight quenching of its emission, and then (at $P / D>1)$ it followed by the fluorescence enhancement. The fluorescence polarization degree, $p$, gradually increases reaching 0.2 at $P / D=7$ and continues to rise.
As it was reported earlier [31, 32], at low $P / D$ ratios cationic porphyrins interact with linear polyanions of nucleic acids presumably by the mechanism of outside electrostatic binding to its phosphate backbone with/without self-stacking. This process is generally cooperative, and in the case of long polyanions (DNA, synthetic polynucleotides etc.) the formation of extended porphyrin stacks on their exterior usually results in the substantial quenching of the dye fluorescence [33, 34]. So, for CatPheo- $a$ bound to long quadruplex poly $(\mathrm{G})$, a strong decrease in the emission intensity was observed by us at $P / D<1$ [9]. It was characterized by linear dependence of $I / I_{0}$ on $P / D$ and residual level of the dye fluorescence (at $P / D=1$ ) of $7.5 \%$ in comparison with that for the free dye (Figure 4). In the case of relatively short oligonucleotides, the size of the porphyrin stacks is limited by the oligomer length and the fluorescent quenching can be less. So, for Tel 22 oligonucleotide, which folds to the form 3 guanine tetrads, the stack cannot contain more than 3 porphyrin molecules bound to the phosphates. Furthermore, in aqueous solution free CatPheo- $a$ at $P / D=0$ exists mostly in the dimeric form, for which the fluorescence is already partially quenched. Thus, if we suppose that the emission changes observed in the present study at $P / D<0.7$ are conditioned by outside electrostatic binding of charged CatPheo- $a$ molecules to Tel22 phosphates with self-stacking of their chromophores, then insignificant value of the fluorescence quenching observed for CatPheo- $a+$ Tel22 in the initial range of titration curve (Figure 4) can be explained by assuming that the short stacks of the dye bound to Tel22 do not fluoresce or weakly fluoresce, like the free 
dye dimers. Similar shape of the titration curve and a magnitude of the fluorescence quenching at low $P / D$ ratios were observed by us earlier upon binding of porphyrin-imidazophenazine conjugate, $\mathrm{TMPyP}^{3+}-\mathrm{ImPzn}$, to the same Tel22 antiparallel quadruplex [35]. In a free state this conjugate formed internal heterodimer with stacking of the chromophores, and addition of the oligonucleotide solution was assumed to induce the disintegration of these dimers with subsequent binding of their porphyrin moieties to Tel 22 phosphates accompanied by macrocycle self-stacking.

The second binding type prevails at $P / D>1$ and it is characterized by the enhancement of CatPheo- $a$ emission (Figures 4,3 ) with a further increase in the dye fluorescence polarization degree. An increase in the fluorescence intensity $\left(I / I_{0}=2\right.$ at $\left.P / D=7\right)$ was accompanied by $14 \mathrm{~nm}$ red shift of emission band maximum (Figure 3) that can indicate a withdrawal of

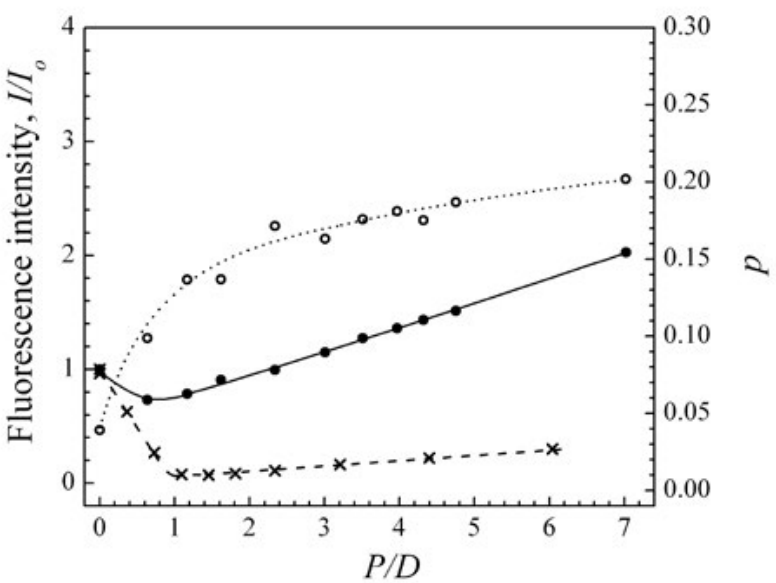

Fig. 4. Dependencies of relative fluorescence intensity, $I / I_{0},(\bullet)$ and fluorescence polarization degree, $p,(\circ)$ on $P / D$ are presented for CatPheo- $a+$ Tel22. The experimental conditions are like in Fig. $3, \lambda_{\text {exc }}=633 \mathrm{~nm}$, $\lambda_{\text {obs }}=677 \mathrm{~nm}$. For comparison $I / I_{0}$ vs $P / D$ is shown for CatPheo- $a+\operatorname{poly}(\mathrm{G})(\times)[9]$. the CatPheo- $a$ molecules from water environment. A high magnitude of the fluorescence polarization $(p=0.2$ at $P / D=7)$ points out the hindering of rotational motion of bound molecules. Unfortunately, the methods used could not provide precise information on the orientation of dye molecules with respect to G4. This mode could be attributed to either the interaction of single CatPheo- $a$ macrocycles with guanine tetrads through $\pi$-stacking (for example, through the end stacking with the terminal G4 tetrad) or their intercalation between the tetrads, or incorporation of the macrocyclic chromophore into the Tel22 quadruplex groove, i.e. the type of binding remains questionable. From the literature data [36] it is known that in the antiparallel basket-type quadruplex formed by Tel22 in $\mathrm{Na}^{+}$-containing solution both terminal G-tetrads are hindered either by the lateral loops or by the diagonal

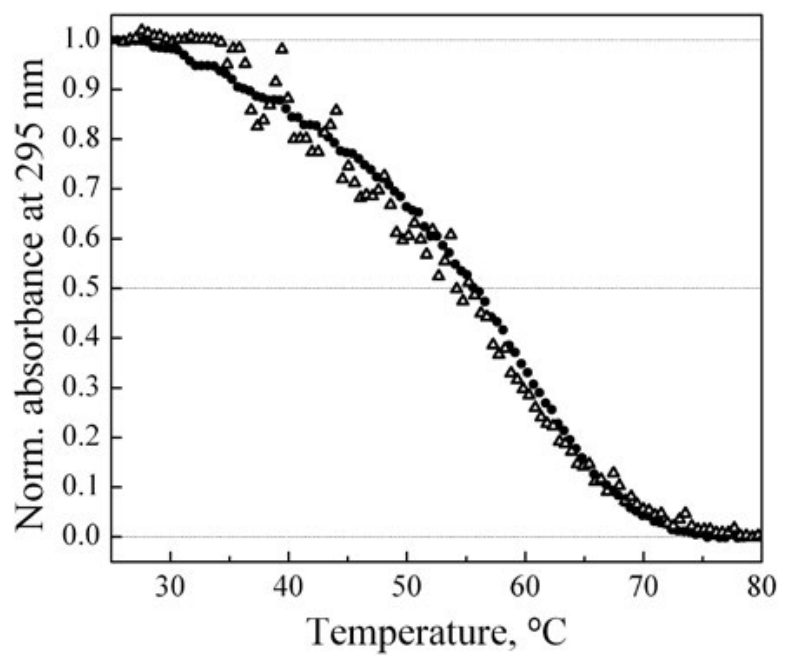

Fig. 5. Normalized absorption melting profiles registered at $295 \mathrm{~nm}$ for Tel22 alone (•) and for its complex with CatPheo- $a$ at $P / D=0.7(\Delta)$. The experimental conditions are as in Fig. 3. Oligonucleotide concentration was 30 $\mu \mathrm{M}$ (in strands). 
loop that runs across the terminal G-tetrad and the bases of which stack onto it. However, it may be possible that the ligand can displace the obstructing bases of the loops or bind to other elements of the G-quadruplex [36]. Perhaps, it can bind to the quadruplex grooves which in this conformation of Tel22 are accessible for dye molecules and the largest of them reaches $18.4 \AA$ in width [18].

Substantial enhancement of porphyrin fluorescence at high $P / D$ ratios was observed earlier upon binding of cationic and neutral Pheophorbide- $a$ derivatives to quadruple $\operatorname{poly}(\mathrm{G})[9,37]$, as well as for the complexes formed by $\mathrm{TMPyP}^{3+}$ porphyrin with poly $(\mathrm{G})$ [38] and Tel22 [35], porphyrin-imidazophenazine conjugate metalated by $\mathrm{Zn}^{2+}$ and $\mathrm{Mn}^{3+}$ with $\operatorname{poly}(\mathrm{G})$ and Tel22 $[39,35]$. At the same time, no enhancement of the CatPheo- $a$ emission was observed upon its binding to double stranded poly $(\mathrm{G}) \cdot \operatorname{poly}(\mathrm{C})$ and $\operatorname{poly}(\mathrm{A}) \cdot \operatorname{poly}(\mathrm{U})$ [9], as well as to single stranded poly $(\mathrm{P})$ biopolymers [8]. Therefore, the fluorescence intensity increased upon binding of these porphyrin derivatives only to the G-quadruplex structures.

An existence of different types of CatPheo- $a$ binding to Tel22 quadruplex is conditioned by the specific features of its structure. Planar macrocyclic chromophore of CatPheo- $a$ provides $\pi-\pi$ stacking with guanine quartets (end stacking with terminal tetrad, incorporation into the quadruplex groove, or, less likely, intercalation between the adjacent tetrads). The process is controlled by hydrophobic and van der Waals interactions and dominates at the polymer excess (high $P / D$ ). At the same time, the side chain of CatPheo- $a$ containing positively charged trimethylammonium group pro- vides the electrostatic interaction of the dye with the negatively charged phosphate backbone of oligonucleotide which can be accompanied by the formation of chromophore stacks or $\pi$-stacked complexes of macrocycle with nucleic bases in the loops. This binding type prevails at the dye excess (low $P / D)$.

Effect of CatPheo-a on Tel22 folding: absorption melting study. To determine whether CatPheo- $a$ affects the folding of Tel 22 oligonucleotide, thermal denaturation of the samples were performed. Figure 5 shows UV melting curves registered at $295 \mathrm{~nm}$ for both Tel22 alone and its mixture with CatPheo- $a$ $(P / D=0.7)$ where the pheophorbide compound is in excess and the oligonucleotide lattice is saturated with the dye. It is seen that both curves are monophasic. They have sigmoid shape and exhibit hypochromic effect at the wavelength of observation. The curves corresponding to quadruplex $\rightarrow$ single strand conformational transition $(4 \rightarrow 1)$ were constructed from the melting data using the standard procedure [40] as it is shown in Figure 6. Here the fraction of folded oligonucleotide (i.e. the fraction of the oligomer strands forming G-quadruplex), $\Theta$, was calculated using the equation:

$$
\Theta(t)=\frac{A_{S S}-A}{A_{S S}-A_{G 4}}
$$

where $A_{S S}$ - absorption of totally denatured complex, $A_{G 4}$ - absorption of the quadruplex sample, $A$ - current absorption value.

To estimate the changes in the thermodynamic parameters of Tel22 quadruplex folding induced by CatPheo- $a$ binding the experimental transition curves corresponding to the samples 
with and without dye were fitted to the equation based on the two-state binding model [40]:

$$
\begin{aligned}
& \ln \frac{\Theta}{(1-\Theta)^{2} C}=\frac{\Delta S}{R}-\frac{\Delta H}{R T} \\
& \Delta G=\Delta H-T \Delta S
\end{aligned}
$$

where $C$ is total molar concentration of Tel22 (in strands), $\Delta H$ is enthalpy change, $\Delta S$ is entropy change, $\Delta G$ is Gibbs standard free energy change.

The thermodynamic values determined were summarized in Table 1 along with the transition midpoint temperatures, $\mathrm{T}_{\mathrm{m}}$. As can be seen from the table, the thermally induced conformational transition from quadruplex to single strand $(4 \rightarrow 1)$ for individual Tel22 has $\mathrm{T}_{\mathrm{m}}=55.6{ }^{\circ} \mathrm{C}$. This value is in agreement with $\mathrm{T}_{\mathrm{m}}=56^{\circ} \mathrm{C}$ reported in [41] for the same system. It is seen, that cationic pheophorbide slightly decreases the transition midpoint temperature to $\mathrm{T}_{\mathrm{m}}=54.7^{\circ} \mathrm{C}$. Also the dye binding to Tel22 slightly changes the enthalpy and entropy of $4 \rightarrow 1$ transition, gives destabilizing increment in the Gibbs standard free energy calculated at physiological temperature $37{ }^{\circ} \mathrm{C}$ that results in a 2-fold reduction of apparent equilibrium constant for the Tel22 quadruplex folding.
From literature data it is known that some other porphyrin derivatives, in particular, the tetracationic derivative TMPyP4, destabilize the quadruplex structures formed by certain oligonucleotide sequences [42-44]. For example, binding of the two molecules, where substituents (methyl groups) are introduced at ortoposition of pyridyl rings, to d(TTAGGG) ${ }_{4}$ oligomer, which is similar to Tel22, decreases the thermostability of G-quadruplex reducing its $\mathrm{T}_{\mathrm{m}}$ by $8^{\circ} \mathrm{C}$ [42]. Addditionally, this compound unfolds the extremely stable G-quadruplex in MT3-MMP mRNA [43] and destabilizes the tetraplex structures oaf $d(C G G)_{n}$ [39]. NiTMPyP4 complex unfolds the quadruplex structure of Tel22 in $\mathrm{Na}^{+}$containing solution [45].

Moreover, it is known that binding of porphyrin dyes to G-quadruplexes can induce changes in their topology. For example, TMPyP4 promotes the conversion of Tel22 quadruplex from the basket to the hybrid type in $\mathrm{K}^{+}$containing solution [46]. So, it can be one of possible reasons for G4-destabilizing effect of CatPheo- $a$.

In such a way CatPheo- $a$ efficiently binds to quadruplex DNA, however, it is not a G-quadruplex stabilizer. At the same time, its ability to generate efficiently singlet oxygen makes it a promising photosensitizer for PDT of tumors.

Table 1. Thermodynamic parameters of G-quadruplex formation by Tel22 sequence in the absence and presence of CatPheo- $a$

\begin{tabular}{l|c|c|c|c|c|c|c}
\hline \multicolumn{1}{c|}{ Compound } & $\mathrm{T}_{\mathrm{m}}\left({ }^{\circ} \mathrm{C}\right)$ & $\mathrm{C}(\mu \mathrm{M})^{\mathrm{a}}$ & $P / D$ & $-\Delta \mathrm{H},(\mathrm{kcal} / \mathrm{mol})$ & $-\Delta \mathrm{S},(\mathrm{cal} / \mathrm{mol} \cdot \mathrm{K})$ & $-\Delta \mathrm{G}^{\mathrm{b}},(\mathrm{kcal} / \mathrm{mol})$ & $\mathrm{K}_{\mathrm{eq}}{ }^{\mathrm{c}},\left(\mathrm{M}^{-1}\right)$ \\
\hline Tel22 & 55.6 & 17.5 & 0.0 & 52 & 134.9 & 10.15 & $1.4 \cdot 10^{7}$ \\
\hline CatPheo- $a+$ Tel22 & 54.7 & 30.0 & 0.7 & 51.8 & 135.8 & 9.69 & $6.7 \cdot 10^{6}$ \\
\hline
\end{tabular}

a In strands

${ }^{\mathrm{b}}$ Data were calculated at $\mathrm{T}=310 \mathrm{~K}$ using equation $\Delta G=\Delta H-T \Delta S$

${ }^{\mathrm{c}}$ Data were calculated at $\mathrm{T}=310 \mathrm{~K}$ using equation $K_{e q}=e^{-\Delta G_{/ R T}}$ 


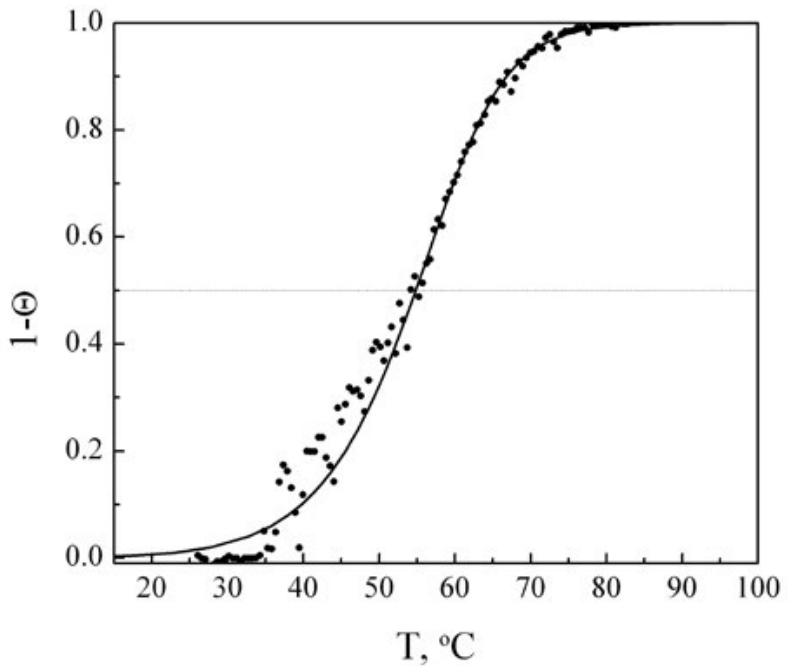

Fig. 6. Dependence of fraction of unfolded Tel22 molecules on the temperature in the presence of CatPheo- $a$ $(P / D=0.7)$. Solid line represents the best fits to the experimental data obtained using two-state binding model.

\section{Conclusions}

In the present study we have focused on binding of cationic Pheophorbide- $a$ derivative to $\mathrm{Na}^{+}$-stabilized 22-mer sequence 5'$\mathrm{d}\left[\mathrm{AG}_{3}\left(\mathrm{~T}_{2} \mathrm{AG}_{3}\right)_{3}\right]-3^{\prime}$, a fragment of human telomeric DNA (Tel22), forming an antiparallel quadruplex and effect of the dye on the Tel22 quadruplex unfolding. CatPheo- $a$ has much improved water solubility as compared with the parent Pheo- $a$ dye. The positively charged side group of this compound facilitates its binding to negatively charged nucleic acids. The investigation has been performed at various [DNA bases]/[CatPheo- $a$ ] ratios using several spectroscopic techniques.

It was shown that CatPheo- $a$ efficiently binds to the Tel22 G4 structure. Availability of two competitive binding modes was established from the biphasic character of the fluorescence titration curve. The first one prevails at $P / D<1$ and manifests itself by the fluorescence quench- ing. It is supposed to be outside binding of CatPheo- $a$ to the Tel22 phosphates accompanied by the formation of the short dye stacks on the quadruplex exterior. Not very high value of the fluorescence quenching can be explained by dimerization of the free dye. The second binding type predominates at $P / D>1$ and is accompanied by enhancement of the dye emission as well as $14 \mathrm{~nm}$ red shift of the fluorescence band. An increase in the fluorescence polarization degree up to 0.2 indicates the restriction of rotation motion for the bound dye molecules. The transformations in the absorption spectrum are less pronounced (4 and $10 \mathrm{~nm}$ for Soret and longwave Q-band respectively).

The effect of CatPheo- $a$ on the thermodynamic parameters of the Tel22 quadruplex folding was determined from the absorption melting experiments. It was found that CatPheo- $a$ ligand slightly destabilizes the quadruplex structure decreasing its midpoint $4 \rightarrow 1$ transition temperature by approximately $1{ }^{\circ} \mathrm{C}$. Destabilizing increment in the Gibbs standard free energy of the quadruplex folding at physiological temperature of $37^{\circ} \mathrm{C}$ through the dye binding was estimated as $0.46 \mathrm{kcal} / \mathrm{mol}$ that results in a 2-fold decrease of the corresponding apparent equilibrium binding constant from $1.4 \cdot 10^{7}$ to $6.7 \cdot 10^{6} \mathrm{M}^{-1}$.

In ethanol solution the dye exhibits a $15 \%$ higher efficiency of the singlet oxygen generation as compared to the parent Pheo- $a$ compound that suggests its improved photodynamic activity. So CatPheo- $a$ can be considered as a promising photosensitizer for the PDT of tumors. These data reinforce the potential applications of pheophorbides.

The data on CatPheo- $a$ binding to G4 DNA reported in this study could be helpful for a 
rational design of novel porphyrins and structurally related compounds with enhanced affinity for the telomeric quadruplex structures as potential telomerase inhibitors with antitumor properties.

\section{Funding}

I.D. and L.D. acknowledge the support from the NAS of Ukraine program "Molecular and Cellular Biotechnologies for Medicine, Industry and Agriculture" (grant No. 43/18).

\section{REFERENCES}

1. Rabinowitch E. Spectra of porphyrins and chlorophyll. Rev Mod Phys. 1944; 16(3-4): 226-35.

2. Gouterman M. Spectra of porphyrins. J Mol Spectrosc. 1961; 6: 138-63.

3. Photodynamic Medicine: From Bench to Clinic (Comprehensive Series in Photochemical \& Photobiological Sciences, vol. 15. Ed. H Kostron and T Hasan, 1st edn Cambridge, UK: RSC, 2016. 650 p.

4. Hong EJ, Choi DG, Shim MS. Targeted and effective photodynamic therapy for cancer using functionalized nanomaterials. Acta Pharm Sin B. 2016;6(4):297-307.

5. Wang KK, Li J, Kim BJ, Lee JH, Shin HW, Ko SH, Lee WY, Lee CH, Jung SH, Kim YR. Photophysical properties of pheophorbide-a derivatives and their photodynamic therapeutic effects on a tumor cell line in vitro. Int J Photoenerg. 2014 (2014):793723.

6. Yano S, Hirohara S, Obata M, Hagiya Y, Ogura S, Ikeda A, Kataoka H, Tanaka M, Joh T. Current states and future views in photodynamic therapy. $J$ Photochem Photobiol C: Photochem Rev. 2011; 12(1): 46-67.

7. Krasnovsky AA Jr, Neverov KV, Egorov SYu, Roeder B, Levald T. Photophysical studies of pheophorbide a and pheophytin a. Phosphorescence and photosensitized singlet oxygen luminescence. J Photochem Photobiol B. 1990;5(2):245-54.

8. Ryazanova O, Voloshin I, Dubey I, Dubey L, Zozulya $V$. Fluorescent studies on cooperative binding of cationic pheophorbide-a derivative to polyphosphate. Ann N Y Acad Sci. 2008;1130:293-9.
9. Ryazanova OA, Voloshin IM, Dubey IYa, Dubey LV, Zozulya VN. Spectroscopic studies on binding of cationic Pheophorbide-a derivative to model polynucleotides. IFMBE Proc. 2008; 20: 397-400.

10. Hänsel-Hertsch R, Di Antonio M, Balasubramanian $S$. DNA G-quadruplexes in the human genome: detection, functions and therapeutic potential. Nat Rev Mol Cell Biol. 2017;18(5):279-284.

11. Rhodes D, Lipps HJ. G-quadruplexes and their regulatory roles in biology. Nucleic Acids Res. 2015;43(18):8627-37.

12. Chambers VS, Marsico G, Boutell JM, Di Antonio M, Smith GP, Balasubramanian S. High-throughput sequencing of DNA G-quadruplex structures in the human genome. Nat Biotechnol. 2015;33(8):877-81.

13. Bochman ML, Paeschke K, Zakian VA. DNA secondary structures: stability and function of G-quadruplex structures. Nat Rev Genet. 2012;13(11):770-80.

14. Neidle $S$. Quadruplex Nucleic Acids as Novel Therapeutic Targets. J Med Chem. 2016;59(13):59876011.

15. Maji B, Bhattacharya S. Advances in the molecular design of potential anticancer agents via targeting of human telomeric DNA. Chem Commun (Camb). 2014;50(49):6422-38.

16. Negrutska VV, Dubey LV, Ilchenko MM, Dubey IY. Design and study of telomerase inhibitors based on G-quadruplex ligands. Biopolym Cell. 2013; 29(3): 169-76.

17. TRAPeze ${ }^{\circledR}$ Telomerase Detection Kit.- Temecula, CA, USA: Chemicon International, 2005. 39 p.

18. Wang Y, Patel DJ. Solution structure of the human telomeric repeat d[AG3(T2AG3)3] G-tetraplex. Structure. 1993;1(4):263-82.

19. Monchaud D, Teulade-Fichou M-P. G4-FID: a fluorescent DNA probe displacement assay for rapid evaluation of quadruplex ligands. In: P. Baumann (Ed.) G-Quadruplex DNA: Methods and Protocols. New York: Humana Press, 2010: 257-71.

20. Zozulya V, Blagoi Y, Löber G, Voloshin I, Winter S, Makitruk V, Shalamay A. Fluorescence and binding properties of phenazine derivatives in complexes with polynucleotides of various base compositions and secondary structures. Biophys Chem. 1997;65(1): $55-63$. 
21. Zozulya VN, Ryazanova OA, Voloshin IM, Glamazda AY, Karachevtsev VA. Spectroscopic detection of tetracationic porphyrin $\mathrm{H}$-aggregation on polyanionic matrix of inorganic polyphosphate. J Fluoresc. 2010;20(3):695-702.

22. Lakowicz JR. Principles of Fluorescent Spectroscopy, 3rd ed. New York: "Springer", 2006; 954 p.

23. Mergny JL, Phan AT, Lacroix L. Following Gquartet formation by UV-spectroscopy. FEBS Lett. 1998;435(1):74-8.

24. Shkirman SF, Solov'ev KN, Kachura TF, Arabei SA, Skakovskii ED. Interpretation of the Soret band of porphyrins based on the polarization spectrum of N-methyltetraphenylporphin fluorescence. $J$ Appl Spectrosc. 1999; 66(1): 68-75.

25. Gouterman $M$, Stryer L. Fluorescence polarization of some porphyrins. $J$ Chem Phys. 1962; 37: 2260-6.

26. Gurinovich GP, Sevchenko AN, Solov'ev KN. The spectroscopy of porphyrins. Sov Phys Usp. 1963; 6(1): 67-105.

27. Roeder B, Wabnitz H. Time-resolved fluorescence spectroscopy of hematoporphyrin, mesoporphyrin, pheophorbide a and chlorin e6 in ethanol and aqueous solution. J Photochem Photobiol B. 1987;1(1):103-13.

28. Mansouri S, Fery-Forgues S, Meunier B, Paillons N. Organization processes of a pyropheophorbidespermidine conjugate in the presence or absences of DNA. J Chem Soc Perkin Trans. 2 1996; 8: 1649-54.

29. Eichwurzel I, Stiel H, Röder B. Photophysical studies of the pheophorbide a dimer. J Photochem Photobiol B. 2000;54(2-3):194-200.

30. Zeug A, Zimmermann J, Röder B, Lagorio MG, San Román E. Microcrystalline cellulose as a carrier for hydrophobic photosensitizers in water. Photochem Photobiol Sci. 2002;1(3):198-203.

31. Pasternack RF, Gibbs EJ, Villafranca JJ. Interactions of porphyrins with nucleic acids. Biochemistry. 1983;22(23):5409-17.

32. Fiel RJ. Porphyrin-nucleic acid interactions: a review. J Biomol Struct Dyn. 1989;6(6):1259-74. Review.

33. Schwarz $G$, Klose $S$, Balthasar $W$. Cooperative binding to linear biopolymers. 2 . Thermodynamic analysis of the proflavine-poly(L-glutamic acid) system. Eur J Biochem. 1970;12(3):454-60.
34. Schwarz G, Balthasar W. Cooperative binding to linear biopolymers. 3. Thermodynamic and kinetic analysis of the acridine orange-poly(L-glutamic acid) system. Eur J Biochem. 1970;12(3):461-7.

35. Zozulya VN, Ryazanova OA, Voloshin IM, Dubey LV, Dubey IYa. Spectroscopic studies on binding of porphyrin-phenazine conjugate to intramolecular G-quadruplex formed by 22-mer oligonucleotide. Int Rev Biophys Chem. 2011; 2(4): 112-9.

36. Nicoludis JM, Miller ST, Jeffrey PD, Barrett SP, Rablen PR, Lawton TJ, Yatsunyk LA. Optimized end-stacking provides specificity of N-methyl mesoporphyrin IX for human telomeric G-quadruplex DNA. J Am Chem Soc. 2012;134(50):20446-56.

37. Ryazanova OA, Voloshin IM, Dubey LV, Zozulya VN. Spectroscopic study of pheophorbide-a methyl ether binding to synthetic polynucleotides and DNA. Biophys. Bull. 2009; 23 (2): 20-9.

38. Ryazanova O, Zozulya V, Voloshin I, Glamazda A, Dubey I, Dubey L, Karachevtsev V. Interaction of a tricationic meso-substituted porphyrin with guaninecontaining polyribonucleotides of various structures. Methods Appl Fluoresc. 2016;4(3):034005.

39. Ryazanova O, Zozulya V, Voloshin I, Dubey L, Dubey I, Karachevtsev V. Binding of Metallated PorphyrinImidazophenazine Conjugate to Tetramolecular Quadruplex Formed by Poly(G): a Spectroscopic Investigation. J Fluoresc. 2015;25(6):1897-904.

40. Marky LA, Breslauer KJ. Calculating thermodynamic data for transitions of any molecularity from equilibrium melting curves. Biopolymers. 1987; 26(9):1601-20.

41. Mergny JL, Phan AT, Lacroix L. Following Gquartet formation by UV-spectroscopy. FEBS Lett. 1998;435(1):74-8.

42. Dutikova YV, Borisova OF, Shchyolkina AK, Lin J, Huang S, Shtil AA, Kaluzhny DN. 5,10,15,20-Tetra(N-methyl-3-pyridyl)porphyrin destabilizes the antiparallel telomeric quadruplex d(TTAGGG)4. Mol Biol. 2010; 44(5): 823-31.

43. Morris MJ, Wingate KL, Silwal J, Leeper TC, Basu S. The porphyrin TmPyP4 unfolds the extremely stable G-quadruplex in MT3-MMP mRNA and alleviates its repressive effect to enhance translation in eukaryotic cells. Nucleic Acids Res. 2012;40(9):4137-45. 
44. Weisman-Shomer P, Cohen E, Hershco I, Khateb S, Wolfovitz-Barchad O, Hurley LH, Fry M. The cationic porphyrin TMPyP4 destabilizes the tetraplex form of the fragile $\mathrm{X}$ syndrome expanded sequence d(CGG)n. Nucleic Acids Res. 2003;31(14):3963-70. 45. Rubio-Magnieto J, Di Meo F, Lo M, Delcourt C, Clément S, Norman P, Richeter S, Linares M, Surin $M$. Binding modes of a core-extended metalloporphyrin to human telomeric DNA G-quadruplexes. Org Biomol Chem. 2015;13(8):2453-63.

46. Gray RD, Li J, Chaires JB. Energetics and kinetics of a conformational switch in G-quadruplex DNA. J Phys Chem B. 2009;113(9):2676-83.

\section{Спектроскопічне дослідження зв'язування катіонного Феофорбіду- $a$ зантипаралельним квадруплексом Tel22}

О. О. Рязанова, В. М.Зозуля, І. М. Волошин, О. Ю. Гламазда, І. Я. Дубей, Л. В. Дубей, В. О. Карачевцев

Мета. Дослідити зв'язування водорозчинної катіонної похідної Феофорбіду- $a$ (CatPheо- $a$ ) з $\mathrm{Na}^{+}$-стабілізованим антипаралельним квадруплексом, утвореним 22-мерним олігонуклеотидом $\mathrm{d}\left[\mathrm{AG}_{3}\left(\mathrm{~T}_{2} \mathrm{AG}_{3}\right)_{3}\right]$ теломерної послідовності ДНК людини (Tel22, PDB ID: 143D). Методи. Абсорбційна та поляризована флуоресцентна спектроскопія були застосовані для визначення властивостей комплексів ДНК-ліганд. Флуоресцентне титрування використовували для оцінки аффінності зв'язування барвника з Tel22. Абсорбційне плавлення було застосоване для оцінки впливу CatPheo- $a$ на термодинамічні параметри формування квадруплексу Tel22. ІЧ-спектроскопію використовували для виявлення генерації синглетного кисню. Результати. Встановлено, що CatPheo- $a$ ефективно зв'язується 3 квадруплексом Tel22 шляхом двох конкуруючих типів зв'язування, які характеризуються протилежними змінами флуоресценції барвника. Визначені спектроскопічні властивості комплексів CatPheo- $a+$ Tel22. Розраховані термодинамічні параметри формування Tel22 квадруплексу з/без CatPheo- $a$. Висновки. Виявлено, що CatPheо- $а$ дестабілізує структуру квадруплекса Tel22, знижуючи в 2 рази рівноважну константу його утворення при $37^{\circ} \mathrm{C}$. Ефективність гене- рації синглетного кисню CatPheо- $a$ вища, ніж у аніонного Pheo- $a$.

Ключові слова: Феофорбід- $a$, квадруплекс Tel22, поляризована флуоресценція, поглинання, плавлення, термодинамічні параметри

\section{Спектроскопическое исследование связывания катионного Феофорбида- $a$ с антипараллельным квадруплексом Tel22}

О. А. Рязанова, В. Н.Зозуля, И. М. Волошин, А. Ю. Гламазда, И. Я. Дубей, Л. В. Дубей, В. А. Карачевцев

Цель. Изучить связывание водорастворимого катионного производного Феофорбида- $a$ (CatPheo- $a$ ) с $\mathrm{Na}^{+}-$ стабилизированным антипараллельным квадруплексом, образованным 22-мерным олигонуклеотидом $\mathrm{d}\left[\mathrm{AG}_{3}\left(\mathrm{~T}_{2} \mathrm{AG}_{3}\right)_{3}\right]$ теломерной последовательности ДНК человека (Tel22, PDB ID: 143D). Методы. Абсорбционная и поляризованная флуоресцентная спектроскопия были применены для установления свойств комплексов ДНК-лиганд. Флуоресцентное титрование применяли для оценки аффинности связывания красителя с Tel22. Абсорбционное плавление было использовано для оценки влияния CatPheo- $a$ на термодинамические параметры формирования квадруплекса Tel22. ИКспектроскопию применяли для обнаружения генерации синглетного кислорода. Результаты. Установлено, что CatPheo- $a$ эффективно связывается с квадруплексом Tel22 посредством двух конкурирующих типов связывания, которые характеризуются противоположными изменениями флуоресценции красителя. Определены спектроскопические свойства комплексов CatPheo- $a+$ Tel22. Рассчитаны термодинамические параметры формирования Tel22 квадруплекса с/без CatPheо- $a$. Выводы. Установлено, что CatPheo- $a$ дестабилизирует структуру квадруплекса Tel22, снижая в 2 раза равновесную константу его образования при $37^{\circ} \mathrm{C}$. Эффективность генерации синглетного кислорода CatPheo- $a$ выше, чем у анионного Pheo- $a$.

Ключевые слова: Феофорбид- $a$, квадруплекс Tel22, поляризованная флуоресценция, поглощение, плавление, термодинамические параметры

Received 22.11.2018 